\title{
Body Image Klien Akibat Pemasangan Fiksasi Eksternal Ekstrimitas Bawah
}

\section{Client's Body Image Because of Lower Extremities External Fixation}

\author{
Ratna Aryani, Heni Nurhaeni, Dinarti
}

\section{Jurusan Keperawatan Polteknik Kesehatan Kementerian Kesehatan Jakarta I}

\begin{abstract}
Abstrak
Fiksasi eksternal adalah metode mengatasi fraktur dengan memasukkan pin ke dalam jaringan kulit, jaringan lunak dan tulang yang dihubungkan dengan rigid external frame. Akibat pemasangan fiksasi eksternal tersebut, klien seperti mendapatkan teror yang sangat menakutkan karena penempatan yang tidak biasa dan bentuk fiksasi eksternal yang besar sehingga memengaruhi body image. Tujuan penelitian ini adalah menggambarkan pengalaman body image klien akibat pemasangan fiksasi eksternal ekstremitas bawah. Metode penelitian yang dilakukan adalah penelitian kualitatif fenomenologi deskriptif ini dilakukan pada tujuh partisipan yang dirawat di RSUP Fatmawati dengan cara purposive sampling pada Oktober November 2012 dengan menggunakan analisis Colaizzi. Hasil penelitian menunjukkan bahwa klien dapat memiliki body image positif atau negatif yang dipengaruhi oleh diri, keluarga dan lingkungan sehingga menimbulkan dampak yang perlu diadaptasi oleh klien. Hasil penelitian ini menjadi acuan bahwa perawat harus memiliki kemampuan memberikan asuhan keperawatan yang komprehensif, termasuk yang terkait dengan masalah psikologis sehingga pemberian asuhan keperawatan akan lebih optimal dengan outcome yang lebih memuaskan.
\end{abstract}

Kata kunci: Fenomenologi dekriptif, body image, fiksasi eksternal

\begin{abstract}
Fiksasi eksternal is a method to overcome the fracture by inserting the pin into the skin tissue, soft tissue and bone are connected by rigid external frame. As a result of the installation of a fiksasi eksternal, clients such as getting a very scary terror due to the unusual placement and shape of a large fiksasi eksternal that affect body image. The research method is descriptive phenomenological qualitative study was conducted in seven participants who were treated at Fatmawati by purposive sampling in October November 2012 with using the Colaizzi analysis. The results show that clients can have a positive body image or negative-that is influenced by self, family and environmental impacts that need to be adapted by the client. This
\end{abstract}

research is a reference that the nurses should have the ability to provide comprehensive nursing care, including psychological issues related to the provision of nursing care that will be optimized with a more satisfactory outcome.

Keywords: Descriptive phenomenology, body image, external fixation

\section{Pendahuluan}

Fiksasi eksternal adalah alat bantu untuk menstabilkan tulang yang mengalami fraktur. Alat tersebut terbuat dari besi yang dilengkapi dengan pin/kawat dan dimasukkan ke dalam jaringan lunak dan menembus masuk ke dalam tulang. ${ }^{1}$ Salah satu rumah sakit yang menangani kasus fraktur dengan fiksasi eksternal adalah RSUP Fatmawati. Rumah sakit tersebut merupakan rumah sakit rujukan nasional yang memiliki Center of Excellence bidang Ortopedi dan Rehabilitasi Medik dengan 10\% kasus fraktur ekstremitas bawah ditangani dengan pemasangan fiksasi eksternal. ${ }^{2}$ Salah satu dampak psikologis yang dialami klien dengan pemasangan fiksasi eksternal adalah gangguan body image. ${ }^{3}$ Hal tersebut terjadi karena ukuran fiksasi eksternal yang besar dengan penempatan yang tidak biasa dan dapat dilihat oleh klien ataupun orang lain sehingga klien sering kali menanyakan penampilan mereka dan apa reaksi orang lain terhadap mereka. ${ }^{4,5}$ Pada akhirnya, klien selalu berusaha menutupi fiksasi eksternal atau menolak melakukan kontak sosial. ${ }^{5}$ Klien sering menganggap pemasangan fiksasi eksternal seperti mendapatkan teror

Alamat Korespondensi: Ratna Aryani, Jurusan Keperawatan Poltekkes Kemenkes Jakarta I, Jl. Wijaya Kusuma Raya No. 47 Cilandak Jakarta Selatan,Hp.085880293939,e-mail:na_istiqomah@yahoo.co.id 
yang menakutkan dan teringat kembali dengan kecelakaan yang menimpa mereka. ${ }^{6}$

Perubahan psikologis body image membutuhkan waktu untuk diadaptasi dengan baik oleh klien. Adaptasi secara fisik biasanya akan tercapai pada bulan pertama setelah pemasangan fiksasi eksternal, namun sayangnya tidak disebutkan kapan klien dapat beradaptasi dengan perubahan psikologisnya. ${ }^{7}$ Peran teman, keluarga dan perawat sangat penting untuk memberikan dukungan mental kepada klien. Penelitian sebelumnya dengan menggunakan metode kuantitatif deskriptif di Rumah Sakit Turki dengan jumlah sampel 50 orang yang terpasang fiksasi eksternal menyimpulkan bahwa tidak ada hubungan yang signifikan antara gangguan body image dan harga diri (self-esteem) dengan pemasangan fiksasi eksternal. ${ }^{8}$ Penelitian ini merekomendasikan untuk dilakukan penelitian dengan cara mengkaji klien secara individual. Penelitian lain yang serupa juga dilakukan peneliti lain dengan menggunakan metode research review dengan mengumpulkan publikasi riset dari tahun 1990 sampai dengan 2003 yang terkait dengan klien yang terpasang fiksasi eksternal. ${ }^{3}$ Penelitian tersebut merekomendasikan untuk dilakukan penelitian lebih lanjut dengan menggunakan berbagai pertanyaan langsung kepada klien yang terpasang fiksasi eksternal.

Penelitian kualitatif dengan metodologi fenomenologi deskriptif tentang pengalaman klien yang terpasang fiksasi eksternal masih sangat terbatas, terlebih lagi di Indonesia. Penelitian kualitatif adalah peneltian yang berfokus pada proses memahami hidup seseorang yang kompleks dan kemudian membangunnya ke dalam gambaran yang lengkap dari suatu fenomena. ${ }^{9}$ Berdasarkan fenomena dan rekomendasi penelitian-penelitian di atas, penulis tertarik mengadakan penelitian kualitatif studi fenomenologi tentang body image klien akibat pemasangan fiksasi eksternal ekstremitas bawah.

\section{Metode}

Penelitian dengan metodologi fenomenologi deskriptif kualitatif ini menggali body image klien fraktur dengan fiksasi eksternal ekstremitas bawah. Rekrutmen partisipan dilakukan dengan purposive sampling dengan tujuh partisipan karena telah terjadi saturasi data. Karakteristik partisipan berusia $18-50$ tahun, mampu menceritakan pengalaman dengan baik, tidak mengalami gangguan kognitif berdasarkan rekam medis, berpengalaman terpasang fiksasi eksternal maksimal tiga bulan dan saat ini masih terpasang, mampu berkomunikasi verbal bahasa Indonesia yang dapat dimengerti peneliti, bersedia berpartisipasi dan menyepakati informed consent yang diberikan. Calon partisipan yang dikunjungi ke rumah mempunyai data rekam medik, tinggal di wilayah Jabodetabek dengan alamat jelas dan nomor telepon yang dapat dihubungi.
Peneliti melakukan wawancara mendalam dengan menggunakan alat bantu pedoman wawancara yang berisi pertanyaan-pertanyaan penelitian dan field note selama 45 - 60 menit dengan frekuensi $1-2$ kali pertemuan. Hasil wawancara direkam dengan menggunakan kamera digital.

\section{Hasil}

Hasil penelitian ini terdiri dari dua tema utama yang memaparkan body image klien akibat pemasangan fiksasi eksternal serta dampak dan proses adaptasi klien.

\section{Respons Body Image}

Temuan dalam penelitian ini mengungkapkan bahwa respons body image yang berasal dari klien dapat berupa respons yang positif dan negatif. Hal ini dipengaruhi oleh individu klien, keluarga dan lingkungan. Dua partisipan berespons positif terhadap body image-nya dengan cara tidak merasa malu dan menerima keadaan. Hal ini tampak pada ungkapan partisipan yang menyatakan:

“...Alhamdulillah saya sih ga ada rasa minder atau gimana-gimana...walaupun kondisi gini jelek yang penting sembuh aja... Ngga di bungkus, kalau di bungkus kaya sarang tawon lebar...” (P1)

Partisipan lain menyatakan respons negatif terhadap body image-nya, terutama jika harus bertemu dengan keluarga pasangan sehingga menarik diri dari lingkungan keluarga istri. Hal tersebut disebabkan oleh cara berjalan yang tak lagi sempurna. Berikut ungkapan partisipan tersebut.

“...rasa malu sih ada... jalan ini agak-agak cipang (=timpang). Orang pada ngomong : ohhhh si I (nama klien) pencot-pencot..Masih sering diajak istri jalanjalan tapi kalau diminta ke acara keluarga, Oohh kalau itu ngga deh... sayanya ga pede...”(P4)

Keterbatasan gerak akibat pemasangan fiksasi eksternal juga dirasakan partisipan ke-7 yang mengungkapkan bahwa semenjak memakai fiksasi eksternal, partisipan tidak bisa melakukan banyak aktivitas seperti dahulu. Berikut ungkapan partisipan 7.

“...ohh enak yang dulu ya... yang dulu lebih leluasa dan enjoy....Lebih enjoy itu kemana-mana lebih gampang sebelum operasi. Tapi kalau liat ini ada sih perasaan lama-lama sedikit ribet sih...jalan pake tongkat terus...ga kaya dulu..."(P7)

Partisipan ke-2 juga menyatakan bahwa perubahan penampilan diri membuat kurang tidur. Dia menyatakan bentuk tubuh yang semula gemuk setelah pemasangan fiksasi eksternal menjadi kurus.

"....sering tiap hari ini makanya badan ibu kurus tadinya kan gemuk...ga tau sebabnya. Tengah malam tidur ya tidur jam 9 sampe setengah 10 terus bangun jam 11 sampe pagi ga bisa tidur lagi...pikiran saya sama kaki aja....ya gimana ya abis ini belum dibuka...”(P2) 
Respons yang paling umum diterima dari lingkungan adalah menganggap frame fiksasi eksternal sebagai benda yang mengerikan dan menolak untuk melihat. Hal ini diungkapkan oleh beberapa partisipan.

"Jadi respons mereka tuh ngeri ngeliat tapi memang kita ga kenapa-kenapa tapi mereka yang ngeri karena ada besi yang tajem nusuk-nusuk...”(P1)

Partisipan ke-1 bahkan mengungkapkan pengalaman ditolak pada saat meminta bantuan pada seorang pria karena kondisi kaki yang terpasang fiksasi eksternal. Tak berbeda jauh pengalaman partisipan ke- 4 yang sering disangka seorang pengemis.

“.....kan kita pake benda aneh. Kadang-kadang kita minta buat tolong sebrangin jalan, pada ga mau.... soalnya bawa benda beda kayak gini...., kebanyakan bapakbapak..., dia malah ngeliatin aja ya, dia sangkain aku kabur dari rumah sakit..." (P1)

"....kalau di jalan suka di kasih uang 5 ribu atau 10 ribu tapi saya tolakin terus saya bilang maaf ibu saya hanya ingin jalan kok bukan minta-minta. Akhirnya dia yang minta maaf...” (P4)

Partisipan ke-7 mengungkapkan pernah berpikir untuk mengamputasi kakinya atas anjuran guru dan temanteman di sekolah, tetapi kakak partisipan menolak dan terus memberikan dukungan. Berikut ungkapan partisipan.

“....bahkan guru saya ngomong kenapa ga diaputasi aja terus pake kaki palsu biar jalan enjoy. Kamu bisa enjoy, kata guru itu. Setelah dipikir semua udah setuju untuk diamputasi tapi kakak sama petugas sini bilang jangan...ini kaki masih hidup....Alhamdulillah perkataan kaka bener..." (P7)

\section{Dampak dan Proses Adaptasi}

Dampak dan proses adaptasi dapat dikategorikan menjadi positif dan negatif. Partisipan menyatakan bahwa pemasangan fiksasi eksternal memberikan dampak yang negatif dalam beradaptasi. Hal ini dikarenakan karena partisipan kehilangan kemandiriannya dan pekerjaan. Hal ini diungkapkan partisipan dengan ungkapan:

"Ibu ga ngapa-ngapain...tidak lagi bisa berjualan combro dan pisang.... ya ga ngaji-ngaji yang duluan 6 bulan di copok nah yang ini ga boleh turun jadi ga kemanamana..." (P2)

Partisipan ke-4 bahkan menjadi tergantung sangat tergantung pada obat anti nyeri. Ini ungkapannya:

"Methadone...tiap hari saya pakai methadone.."(P4)

Setelah pemasangan fiksasi eksternal, partisipan mengatakan bahwa yang lebih sulit dilakukan adalah mematutkan diri dalam berpakaian sehingga merasa harus menjadi lebih menjaga penampilan. Hal ini diungkapkan partisipan sebagai berikut.

"Iya pakaian yang bikin bingung, kalau baju sih enjoy...yang penting enak diliat perempuan ya...sama kelu- arga juga...111111untuk celana, saya agak bingung. Dulu waktu pertama kali pasang pen, saya hanya pake sarung terus kaen putih untuk dalemnya...ya udah lah nyari-nyari itu pakaian dulu....udahlah ga usah pake ini tapi mau tetep juga....cobalah dipaksa dulu....kata dokter, pake celana yang agak besar kamu tinggal bikin. Dan dicoba-coba Alhamdulillah sebulan kemudian dipake...”(P7)

Tiga partisipan menyatakan bahwa mereka menjadi lebih meningkat dalam melakukan ibadah spiritual, termasuk saat ke masjid, melakukan salat wajib dan sunnah serta membaca Al-Qur'an.

“...Aku jadi tambah rajin, Mbak...baca Qur'an juga...”(P5)

Empat partisipan memerlukan waktu beradaptasi secara psikologis terhadap body image kurang lebih $1-4$ bulan. Proses adaptasi tersulit yang dirasakan terutama ketika kembali ke lingkungan rumah, sedangkan ketika di masih dirawat di rumah sakit, lima dari tujuh partisipan menyatakan tidak terlalu bermasalah.

\section{Pembahasan \\ Respons Body Image}

Respons psikologis yang dialami oleh partisipan dalam penelitian ini adalah gangguan body image. Adanya keinginan untuk menarik diri, malu keluar rumah menggunakan tongkat, sering menyebut kaki pincang, tidak bebas dalam bergerak, bahkan adanya keinginan mengamputasi kaki, diungkapkan partisipan terkait dengan body image.

Pernyataan partisipan-partisipan tersebut memiliki persamaan dengan penelitian sebelumnya yang menyebutkan klien dengan pemasangan fiksasi eksternal rentan terhadap gangguan body image karena penempatan yang dapat dilihat oleh klien atau orang lain atau karena fiksasi eksternal berada di tempat yang tidak biasa. ${ }^{4}$ Klien yang mempunyai gangguan body image dan harga diri akibat pemasangan fiksasi eksternal seringkali menanyakan penampilan mereka dan apa reaksi orang lain terhadap mereka serta mengalami gangguan psikologis yang berat, misalnya anorexia nervosa. ${ }^{5}$ Namun, tidak semua penelitian mempunyai persamaan dengan hasil penelitian ini. Penelitian kuantitatif deskriptif yang dilakukan di Rumah Sakit Turki terhadap 50 sampel yang terpasang fiksasi eksternal, menyimpulkan tidak ada hubungan signifikan antara gangguan body image dan harga diri (selfesteem) dengan pemasangan fiksasi eksternal. ${ }^{8}$ Adanya perbedaan hasil penelitian ataupun berbeda dengan fenomena yang pada umumnya terjadi, kemungkinan terjadi karena jumlah sampel yang kecil dan pengambilan sampel secara tidak acak. Mereka merekomendasikan melakukan penelitian dengan mengkaji klien secara individual.

Konsep diri yang baik akan menghasilkan mental yang 
sehat, kemampuan koping yang baik, menurunkan risiko depresi dan menghasilkan body image yang baik. ${ }^{10}$ Untuk meningkatkan konsep diri klien, perawat dapat memperkuat apa yang dirasa dan dipikirkan klien dengan memperhatikan ekspresi verbal dan nonverbal klien, memberikan kesempatan kepada klien untuk melakukan perawatan diri sendiri, mengidentifikasi kelemahan dan kekuatan klien, menyampaikan secara verbal dan behavior bahwa klien bertanggung jawab terhadap diri sendiri, menggali koping adaptif dan mal-adaptif respons klien terhadap masalah dan memperkuat hal-hal positif yang dimiliki klien. ${ }^{11}$

Penelitian ini juga mengungkapkan bahwa pemberian informasi yang adekuat menjadi sangat penting agar klien dengan fiksasi eksternal dapat mempunyai koping yang baik. Hal ini dibuktikan dengan adanya kejadian partisipan ke-7 yang mempunyai keinginan untuk mengamputasi kaki ataupun pada partisipan ke-3 yang mempunyai keinginan untuk bunuh diri, tidak terjadi setelah diberikan informasi adekuat dari perawat. Berdasarkan fenomena ini, perawat sudah dapat berperan lebih dalam memberikan asuhan keperawatan sejak, terutama sebelum operasi pemasangan fiksasi eksternal sampai klien pulang ke rumah. Sayangnya sekitar 20\% klien yang terpasang fiksasi eksternal pemberian informasi yang tidak adekuat sering dilupakan. ${ }^{12}$

\section{Dampak dan Proses Adaptasi}

Partisipan pada penelitian ini menyatakan pemakaian fiksasi eksternal berdampak positif dan negatif. Mereka mengungkapkan dampak negatif akibat pemakaian fiksasi eksternal menjadi kehilangan kemandirian, kehilangan pekerjaan, menjadi tergantung terhadap obat yang berefek anti nyeri dan menjadi terganggu proses sosialisasi. Kehilangan kemandirian merupakan dampak yang harus diterima oleh klien dengan pemasangan fiksasi eksternal. Pemakaian fiksasi eksternal akan menyebabkan beberapa keterbatasan, seperti melakukan aktivitas kerumahtanggaan, aktivitas higiene dan aktivitas sosial. ${ }^{13}$ Penelitian lain yang menceritakan pengalaman partisipan yang membutuhkan bantuan orang lain bahkan untuk aktivitas yang sederhana sekalipun, misal menyediakan air untuk mandi atau peralatan keramas, pergi ke tukang jahit untuk memodifikasi beberapa pakaian, membelikan pakaian atau membantu ketika BAK/BAB. ${ }^{2}$

Dampak negatif kedua dalam penelitian ini adalah kehilangan pekerjaan, contohnya pada partisipan ke-2 yang semula bekerja sebagai penjual nasi uduk, partisipan ke3 sebagai supir, partisipan ke-4 sebagai pemulung barang bekas, partisipan ke-5 dan 7 sebagai pelajar dan partisipan ke-6 sebagai karyawan swasta. Semua tidak dapat melakukan aktivitas pekerjaan yang sama seperti ketika belum terpasang fiksasi eksternal. Penelitian lain mengungkapkan 26 partisipan dengan rata-rata pemasangan fiksasi eksternal sekitar 40 bulan menunjukkan gangguan menjalankan rutinitas sekolah atau bekerja, kecuali pada satu klien yang menunjukkan hal yang positif. ${ }^{12}$

Dampak negatif ketiga yang dialami partisipan ke-3 juga adalah adanya ketergantungan terhadap obat yang mempunyai efek anti nyeri. Ia baru saja pulang dari puskesmas untuk mengambil obat anti nyerinya ketika peneliti melakukan wawancara. Hal ini juga pernah terjadi pada enam dari sembilan partisipan dalam penelitian sebelumnya yang menyatakan bahwa mereka mengonsumsi obat anti nyeri untuk meminimalkan rasa nyeri, membuat tenang, menurunkan rasa takut dan khawatir terhadap kematian. ${ }^{14}$

Dampak negatif keempat adalah interaksi sosial menjadi terganggu. Perawat dapat membantu klien untuk melakukan interaksi sosial karena pada beberapa orang menganggap berinteraksi dengan orang lain tidak mudah. ${ }^{15}$ Intervensi keperawatan yang dapat diberikan adalah memberikan waktu kepada klien untuk express feeling, mendampingi klien melakukan interaksi sosial jika diperlukan, mendukung dan memfasilitasi klien untuk melakukan interaksi dan memberikan klien support group.

Pemakaian fiksasi eksternal juga memberikan dampak yang positif antara lain klien menjadi sangat perhatian terhadap penampilan. Partisipan mempunyai kecenderungan untuk berkaca lebih lama sebelum melakukan kontak dengan orang lain. Namun, sayangnya peneliti belum menemukan penelitian lain yang menyebutkan bahwa adanya peningkatan perhatian klien dengan pemasangan fiksasi eksternal terhadap penampilan. Namun suatu penelitian, klien yang mempunyai gangguan body image dan harga diri akibat pemasangan fiksasi eksternal sering menanyakan penampilan mereka dan apa reaksi orang lain terhadap mereka. ${ }^{5}$

Dampak positif kedua adalah adanya peningkatan sisi spiritualitas. Penelitian ini menemukan bahwa hanya 3 dari 7 partisipan (P1, P4 dan P5) yang menyatakan adanya peningkatan spiritualitas. Hal ini perlu menjadi bahan evaluasi dalam memberikan asuhan keperawatan yang menyentuh sisi spiritualitas.

Penelitian sebelumnya dengan metode deskriptif korelasi yang bertujuan mengetahui hubungan antara spiritual perawat dengan pemberian pelayanan spiritual pada klien mereka dengan 173 responden perawat yang berpartisipasi di kota Midwestern, hanya menunjukkan 25\% perawat yang memberikan perhatian spiritual kepada klien. ${ }^{16}$ Penelitian tersebut mengungkapkan beberapa penghalang yang menyebabkan perawat tidak perhatian terhadap aspek spiritual klien adalah keterbatasan waktu $(95 \%)$ perawat dan keterbatasan pengetahuan terhadap kebutuhan spiritual (65\%). Padahal spiritual dibutuhkan untuk mendukung kesehatan individu karena merupakan salah satu sumber kekuatan yang meme- 
ngaruhi kesehatan. ${ }^{17}$ Survei The National Institute of Health-care yang dilakukan pada masyarakat Amerika dengan kesimpulan hubungan antara spiritual dengan kesehatan. ${ }^{18}$ Survey tersebut menyebutkan bahwa responden mempercayai bahwa doa berperan serta dalam proses penyembuhan $(82 \%)$, Tuhan turut mengintervensi kesembuhan orang-orang yang menderita penyakit berat $(77 \%)$, mendoakan orang lain dapat menyembuhkan orang dengan penyakit berat $(73 \%)$, seharusnya dokter mengadakan doa bersama dengan klien-klien meraka (64\%) dan sekitar 28\% responden mempercayai bahwa iman dapat membuat seseorang merasa sehat. Hasil survei tersebut menjadi dasar spiritual practice dimasukkan juga dalam sistem kesehatan di Amerika, walaupun hubungan antara keduanya masih merupakan misteri dalam pengobatan modern. ${ }^{19}$

Dampak negatif dan positif yang dialami partisipan, mengharuskan klien untuk dapat beradaptasi terhadap segala perubahan. Penelitian ini menyebutkan bahwa empat partisipan memerlukan waktu beradaptasi secara psikologis terhadap body image kurang lebih $4-12$ minggu. Proses adaptasi tersulit yang dirasakan terutama ketika kembali ke lingkungan rumah, sedangkan ketika di masih dirawat di RS, lima dari tujuh partisipan menyatakan tidak terlalu bermasalah. Proses adaptasi psikologis body image relatif lebih lama daripada adaptasi secara fisik.

Pada penelitian sebelumnya, partisipan mencoba beradaptasi dengan perubahan penampilan, misalnya dengan membuat celana pendek yang dimodifikasi, mandi dengan menggunakan washlap atau berjalan menggunakan alat bantu jalan seperti kursi roda atau kruk. ${ }^{2}$ Rata-rata waktu untuk beradaptasi terhadap perubahan dan keterbatasan beraktivitas rumahtangga dan aktivitas higiene adalah 12 minggu. ${ }^{2}$ Bahkan penelitian lain menyebutkan keterbatasan tersebut telah dapat diadaptasi kurang lebih empat minggu. ${ }^{7,13}$ Berdasarkan respons kognitif yang ditampilkan partisipan, dapat disimpulkan bahwa partisipan beradaptasi lebih lambat secara fisik daripada partisipan di penelitian sebelumnya, namun belum ada penelitian yang menyebutkan lama adaptasi secara psikologis. Perbedaan lama adaptasi secara fisik bias disebabkan karena adanya perbedaan durasi, intensitas, feeling competence, penilaian kognitif dan dukungan sosial terhadap stressor. ${ }^{15}$

Berdasarkan fenomena ini, perawat harus mampu membantu klien yang terpasang fiksasi eksternal agar mampu beradaptasi dengan perubahan yang dialami. Perawat dapat membantu klien memfasilitasi klien mendapatkan support system selain dari keluarga, misal dengan klien lain yang mempunyai pengalaman yang sama. Berdiskusi dengan orang yang mempunyai pengalaman sama dapat membantu klien untuk beradaptasi dengan pemasangan fiksasi eksternal.

\section{Kesimpulan}

Klien dengan pemasangan fiksasi eksternal dapat memiliki body image yang positif atau negatif yang dipengaruhi oleh diri, keluarga dan lingkungannya sehingga menimbulkan dampak yang harus diadaptasi oleh klien terkait dengan perubahan yang dialaminya.

\section{Saran}

Berdasarkan penelitian ini, peneliti menyarankan bahwa semua instansi RS perlu memfasilitasi adanya pendidikan dan pelatihan perawat untuk lebih responsif terhadap respons psikologis klien. Hasil pendidikan tersebut akan lebih dikuatkan dengan adanya SOP pemberian edukasi terkait dengan perubahan fisik, psikologis dan sosial sebelum operasi pemasangan fiksasi eksternal dilakukan. Adanya komunitas klien dengan pemasangan fiksasi eksternal layak untuk dicoba sehingga klien yang baru terpasang akan merasa bahwa apa yang dirasakan bukanlah sesuatu yang harus direspons negatif.

Terkait dengan penelitian lebih lanjut, perlu diteliti efektivitas pemberian edukasi terstruktur pada klien sebelum operasi pemasangan fiksasi eksternal serta efektivitas peran serta keluarga dalam membantu adaptasi psikologis klien yang terpasang fiksasi eksternal.

\section{Daftar Pustaka}

1. Santy J, Vincent M, Duffield B. The principles of caring for patients with Ilizarov external fixation. Nursing Standard. 2009; 23 (26): 50-5.

2. Aryani R. Studi fenomenologi: pengalaman klien yang mengalami fraktur ekstremitas bawah dengan pemasangan external fixator. Health Quality. 2011; 33 (1): 1-5.

3. Patterson M. Impact of external fixation on adolescents : An integrative research review. Orthopaedic Nursing. 2006; 25 (5): 300-8.

4. Limb, MK. An examination of the relationships between body image, self-esteem and behavior in adult clients undergoing limb reconstruction procedures. Journal of Orthopaedic Nursing. 2004; 8: 164-70.

5. Santy J. Nursing the patient with an external fixator. Nursing Standard. 2000; 14 (31): 47-52.

6. Limb, MK. Psychosocial issues relating to external fixation of fractures. Nursing Times. 2003; 99 (44): 28-30.

7. Martin L, Farrell M, Lambrenos K, \& Nayagam K. Living with the Ilizarof frame: adolescent perceptions. Journal of Advanced Nursing. 2003; 43 (5): 478-87.

8. Buyukyilmaz F, Sendir M, \& Salmond S. Evaluation of body image and self esteem in patients with external fixation devices: a Turkish perspective. Orthopaedic Nursing. 2009; 28 (4): 169-75.

9. Macnee $\mathrm{C}$. Understanding nursing research: reading and using research in practice. Philadelphia : Lippincott Williams \& Wilkins; 2004.

10. Birndorf S, Ryan S, Auinger P, \& Aten M. High self-esteem among adolescents: longitudinal trends sex differences and protective factors. Journal of Adolescent Health. 2005; 37(3): 194-201.

11. Stuart GW, Laraia MT. Principles and practice of psychiatric nursing. $8^{\text {th }}$ ed. St. Louis: Mosby; 2005. 
12. Ramaker RR, Lagro SWJ, Roermund PMV, Sinnema G. The psychological and social functioning of 14 children and 12 adolescents after Ilizarov leg lengthening. Acta Orthopaedia Scandinavia. 2000; 71 (1): 55-9.

13. Modin M, Ramos T, Stomberg MW. Post operative impact of daily life after primary treatment of proximal/distal tibia fracture with Ilizarof external fixation. Journal of Clinical Nursing. 2009; 18: 3498-506.

14. Patterson M. Adolescent experience with traumatic injury and orthopaedic external fixation: forever changed. Orthopaedic Nursing. 2010; 29 (3): 183-91.
15. Potter PA, Perry AG. Basic nursing: essential for practice. 6th ed. Missouri: Mosby Elsevier; 2007.

16. Vance D. Nurses' attitudes towards spirituality and patient care. Medsurg Nursing. 2001; 10 (5): 264-9.

17. Grant D. Spiritual interventions : how, when and why nurses use them. Holist Nurs Pract. 2004; 18 (1): 36.

18. Maddox M. Spiritual assessments in primary care. Nurse practitioner. 2002; 27 (2): 12-3.

19. Mauk KL, Schmidt NK. Spiritual care in nursing practice. Philadelphia: Lippincott Williams \& Wilkins; 2004. 